\title{
PENGARUH PENGETAHUAN MAHASISWA TENTANG INVESTASI TERHADAP MINAT MAHASISWA BERINVESTASI PADA GALERI INVESTASI SYARIAH IAIN BATUSANGKAR
}

\author{
${ }^{1}$ Fitri Yenti, ${ }^{2}$ Shely Azzara \\ Institut Agama Islam Negeri Batusangkar \\ e-mail: fitriyenti@iainbatusangkar.ac.id \\ Copyright (C) 2021

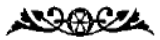

\begin{abstract}
This research was motivated by the least the number of sharia management and accounting students class of 2016 who opened accounts at IPOT GIS IAIN Batusangkar. This study was aimed to determine the effect of student knowledge about investment on students' interest in investing in the Islamic investment gallery of IAIN Batusangkar. The research design was a quantitative methods with a descriptive approach. The population were students of Economics and Islamic Business Faculty who had studied courses on investment and capital markets. The sample were 81 students. The data were collected through distributing questionnaire. Normality, linearity, correlation, determination coefficient, $t$-test, and simple linear regression analysis test were used to analyze the data. The result indicated that students' knowledge of investment had an effect on students' interest in investing in the Islamic investment gallery of IAIN Batusangkar.
\end{abstract}

Keywords: Pengetahuan Investasi, Minat, Investasi

\section{PENDAHULUAN}

Pada era saat ini investasi sudah mulai banyak diminati dan dipraktekkan di kalangan masyarakat ataupun mahasiswa. Hal ini terbukti dengan adanya beberapa investasi seperti saham, obligasi, properti, dan logam mulia. Namun, tidak sedikit dari mereka yang belum mempunyai minat dalam berinvestasi, karena sebagian dari mereka yang belum mempunyai minat dalam berinvestasi, karena sebagian dari mereka beranggapan bahwa berinvestasi itu hal yang sangt sulit dan membutuhkan modal yang besar. Tetapi hal ini berbeda jika seseorang itu mempunyai minat untuk berinvestasi, seseorang tersebut akan bersungguh-sungguh memulai investasi walau dengan modal yang seadanya atau dengan modal seminimal mungkin (Nisa \& Zulaika, 2017)

Galeri Investasi Syariah yang tedapat di IAIN Batusangkar membuat mahasiswa lebih mudah dan cepat dalam mendapatkan informasi dan bergabung untuk menanamkan modal 
dan membeli saham. Oleh karena itu kita melihat minat mahasiswa untuk berinvestasi pada Galeri Investasi Syariah IAIN Batusangkar. Sebelumnya diperlukan langkah-langkah pendahuluan yang mendorong munculnya minat tersebut. Salah satu faktor penentunya adalah tingkat pengetahuan. (Hidayat et al., 2019) menyatakan bahwa untuk melakukan investasi di pasar modal diperlukan pengetahuan yang cukup, pengalaman serta naluri bisnis untuk menganalisis efek-efek mana yang akan dibeli. Pengetahuan yang memadai sangat diperlukan untuk menghindari terjadinya kerugian saat berinvestasi di pasar modal, seperti pada instrumen investasi saham.

Pengetahuan dasar mengenai investasi merupakan hal sangat penting untuk diketahui oleh calon investor. Hal ini bertujuan agar investor terhindar dari praktik-praktik investasi yang tidak rasional (judi), budaya ikutikutan, penipuan, dan resiko kerugian. Diperlukan pengetahuan yang cukup pengalaman serta naluri bisnis untuk menganalisis efek-efek mana yang akan dibeli dalam melakuakan investasi di pasar modal (Hidayat et al., 2019)

Mahasiswa FEBI angkatan 2016 berjumlah 426 orang, yang terdiri dari mahasiswa Jurusan Perbankan Syariah 196 orang, Jurusan Ekonomi Syariah dengan konsentrasi Manajemen Syariah 120 orang, dan Akuntansi Syariah 110 orang. Mahasiswa tersebut sekarang sudah semester 8 dan sudah mempelajari mata kuliah Manajemen Invetasi dan Bursa Efek, Investasi
Keuangan Syariah, Manajeman Investasi Syariah, serta Bursa Efek dan Investasi Syariah. Sehingga setelah proses pembelajaran mata kuliah tentang investasi akan meningkatkan pengetahuan mahasiswa tentang investasi. Dengan meningkatnya pengetahuan mahasiswa tentang investasi akan diketahui minat mahasiswa untuk berinvestasi pada Galeri Investasi Syariah IAIN Batusangkar.

\section{KAJIAN TEORI}

Pengetahuan Pasar Modal merupakan pengetahuan tentang konsep dan manfaat keberadaan pasar modal di Indonesia. Pengetahuan pasar modal terdiri dari pengetahuan tentang pasar modal sebagai wadah investasi resmi, perusahaan, masyarakat dan kelebihan dana, instrumen yang dijual di pasar modal, pasar modal sumber pendanaan.

Pengetahuan Jenis Instrumen Investasi merupakan pengetahuan tentang jenis investasi yang dapat dibedakan menjadi investasi langsung (direct investment) dan investasi tidak langsung (indirect investment). Pengetahuan Jenis Instrumen Investasi terdiri dari pengetahuan tentang Saham Instrumen Keuangan Pasar Modal, Tempat Pembelian Saham, Jangka Waktu Saham, Jangka Waktu Deposito dan Obligasi.

Tujuan berinvestasi adalah untuk mendapatkan keuntungan. Pengetahuan Tingkat Keuntungan Investasi terdiri dari pengetahuan tentang Dividen Keuntungan Investasi Saham Pembagian Laba Perusahaan Kepada 
Investor, (3) Keuntungan yang Diperoleh Dari Saham, (4) Keuntungan Lain yang diperoleh dari Saham, (5) Investasi Saham Lebih Menguntungkan, (6) Investasi Deposito Lebih Menguntungkan.

a. Pengetahuan Tingkat Risiko

Saham dikenal dengan karakteristik imbal hasil tinggi, resiko tinggi (high risk, high return). Artinya saham merupakan surat berharga yang memberikan peluang keuntungan tinggi namun juga berpotensi resiko tinggi (Hidayat et al., 2019). Sikap investor terhadap risiko akan sangat tergantung kepada preferensi investor tersebut terhadap risiko. Investor yang lebih berani akan memilih investasi yang memiliki risiko tinggi, yang diikuti tingkat keuntungan yang tinggi pula. Sebaliknya investor yang tidak mau menanggung risiko yang terlalu tinggi, tentunya tidak akan bisa mengharapkan tingkat keuntungan yang terlalu tinggi. Pengetahuan Tingkat Risiko Investasi terdiri dari pengetahuan tentang (1) Prinsip Investasi Saham, (2) Risiko Investasi Saham, (3) Tidak Memperoleh Dividen Adalah Risiko Investasi Saham, (4) Risiko Kebangkrutan Pada Perusahaan Yang Menjual Saham, (5) Capital Loss Merupakan Kerugian Membeli Saham, (6) Pemegang Saham Pemilik Hak Terakhir Kekayaan Perusahaan, (7) Investasi Saham Berisiko Lebih Tinggi Dibanding Obligasi, (8) Risiko Investasi Saham dan Obligasi, (9)
Manfaat Mengukur Tingkat Risiko, (10) Pilihan Investasi Risiko Rendah, (11) Pilihan Investasi Risiko Tinggi.

b. Pengetahuan Dasar Penilaian Saham Pengetahuan dasar penilaian saham merupakan pengetahuan investor terkait penilaian terhadap saham dengan menghitung IRR, NPV, dan lain-lain, pendapatan atau laba perusahaan yang diharapkan. Uang dapat digunakan sebagai dasar dalam penilaian saham. Pengetahuan dasar penilaian saham terdiri dari pengetahuan tentang (a) Pentingnya Pengetahuan Dasar Investasi, (b) Peran Sekolah Pasar Modal, (c) Peran Mata Kuliah Teori Portofolio, (d) Peran Mata Kuliah Teori Portofolio (Hidayat et al., 2019)

\section{Minat Berinvestasi}

Theory of Planned Behavior, bahwasanya manusia cenderung bertindak sesuai dengan intensi dan persepsi pengendalian melalui perilaku tertentu, dimana intensi dipengaruhi oleh tingkah laku, norma subjektif serta pengendalian perilaku. Dari ketiga hal yang menentukan intensi tersebut, tingkah laku merupakan poin utama yang mampu memprediksi sebuah perilaku. Pada Theory of Planned Behavior ini juga dijelaskan bahwa niat berperilaku (behavioral intention) tidak hanya dipengaruhi oleh sikap terhadap perilaku (attitude towards behavior) dan norma subyektif (subjective norm), tetapi juga dipengaruhi oleh kontrol 
keperilakuan yang dirasakan (perceived behavioral control). Kontrol keperilakuan dipengaruhi oleh pengalaman masa lalu dan perkiraan seseorang mengenai sulit atau tidaknya untuk melakukan perilaku tertentu (Hidayat et al., 2019). Karenanya niat berperilaku dapat menunjukkan perilaku yang akan dilakukan oleh seseorang. Hal ini dapat menjelaskan apabila seorang yang memiliki minat berinvestasi maka dia cenderung akan melakukan tindakantindakan untuk dapat mencapai keinginannya berinvestasi. Misalkan dengan mengikuti pelatihan dan seminar tentang investasi, menerima dengan baik penawaran investasi, dan pada akhirnya melakukan investasi (Hidayat et al., 2019). Ciri-ciri seseorang yang berminat untuk berinvestasi dapat diketahui dengan seberapa berusahanya mereka dalam mencari tahu tentang suatu jenis investasi, mempelajari dan kemudian mempraktikanya. Hal ini senada dengan pendapat (Hidayat et al., 2019) yang menyatakan bahwa minat berinvestasi adalah keinginan untuk mencari tahu tentang jenis suatu investasi dimulai dari keuntungan, kelemahan, kinerja investasi dan lain sebagainya. Ciri lain yang dapat dilihat adalah mereka akan berusaha meluangkan waktu untuk mempelajari lebih jauh tentang investasi tersebut atau mereka langsung mencoba berinvestasi pada jenis investasi tersebut, bahkan menambah "porsi" investasi mereka yang sudah ada.

\section{METODE PENELITIAN}

Penelitian ini menggunakan metode kuantitatif dengan pendekatan deskriptif. Adapun pengertian dari penelitian deskriptif adalah penelitian yang hanya memaparkan situasi atau peristiwa. Penelitian ini tidak mencari atau menjelaskan hubungan atau membuat prediksi. Metode deskriptif bertujuan melukiskan secara sistematis fakta atau karakteristik populasi tertentu secara faktual dan cermat. Penelitian ini menggunakan pendekatan kuantitatif deskriptif dengan menggunakan data primer melalui kuesioner (Anisatus \& Zainal, 2014).

Populasi dalam penelitian ini adalah mahasiswa Fakultas Ekonomi dan Bisnis Islam, yang telah mempelajari mata kuliah tentang investasi dan pasar modal. Sampel dalam penelitian ini adalah sebanyak 81 Mahasiswa. Pengumpulan data pada penelitian ini menggunakan metode kuesioner. Uji coba instrumen dianalisis dengan menggunakan uji validitas dan uji reliabilitas. Teknik analisis data yang digunakan dalam penelitian ini adalah uji normalitas, uji linearitas, uji korelasi, uji koefisien determinasi, uji t, dan analisis regresi linier sederhana.

\section{HASIL PENELITIAN}

Berdasarkan uji validitas, semua pertanyaan dalam peneltian yang di sebar melalui kuesioner dinyatakan valid. Dibuktikan dengan nilai signifikansi $(0,000<0,1)$. Uji reliabilitas semua indikator dinyatakan reliable 
(handal) yang dibuktikan dengan nilai Cronbach's Alpha if Item Deleted lebih dari 0,60 dengan nilai 0,767 untuk variabel $\mathrm{x}$ dan 0,749 untuk variabel $\mathrm{Y}$. Uji Normalitas Kolmogorov-smirnov menghasilkan nilai signifikansi Asymp. Sig. (2tailed) sebesar 0,268 yang lebih besar dari nilai 0,1. Berdasarkan dasar pengambilan keputusan dalam uji normalitas kolmogorov-smirnov, dapat disimpulkan bahwa data berdistribusi normal. Dengan demikian, asumsi normalitas dalam model regresi dinyatakan terpenuhi. Uji lienaritas dengan nilai Deviation from Linearity sebesar 0,772. Karena signifikansi besar dari 0,1 maka dapat disimpulkan bahwa antara variabel pengetahuan mahasiswa tentang investasi terhadap minat mahasiswa berinvestasi terdapat hubungan yang linear.

Dari hasil output SPSS ini diketahui nilai untuk hubungan pengetahuan mahasiswa tentang investasi terhadap minat mahasiswa berinvestasi sebesar 0,000 berarti lebih kecil dari 0,1 maka dapat dikatakan bahwa terdapat hubungan antara pengetahuan dengan minat. Dilihat dari nilai pearson correlation nya sebesar 0,668 berarti tingkat hubungan antara pengetahuan mahasiswa tentang investasi terhadap minat korelasinya kuat. Dan melihat arah hubungan variabel bernilai positif 0,668 berarti pengetahuan mahasiswa tentang investasi berhubungan positif terhadap minat mahasiswa berinvestasi.

Besarnya persentase pengaruh variabel terikat yang disebut koefisien determinasi yang merupakan hasil dari penguadratan $R$ (R2) R Square yakni sebesar 0,446 ini mengartikan bahwa nilai sumbangan pengaruh sebesar 44,6\% sedangkan 55,4\% dipengaruhi oleh faktor lain yang tidak diteliti dalam penelitian ini artinya pengaruh variabel independen $\mathrm{x}$ terhadap $\mathrm{y}$ sebesar 44,6\%. Berdasarkan nilai signifikan uji t sebesar 0,000 0,1 maka hipotesis di terima. Dan disimpulkan Ho ditolak dan $\mathrm{Ha}$ diterima Ini berarti variabel independen mempunyai pengaruh signifikan terhadap variabel dependen.

Dari hasi ouput SPSS pada bagian coefficients, pada kolom B pada constant (a) adalah 10,534, sedangkan nilai pengetahuan mahasiswa tentang investasi (b) 0,590, sehingga bentuk persamaan regresinya dapat ditulis sebagai berikut:

$$
\begin{aligned}
& Y=a+b X \\
& Y=10,534+0,590 X
\end{aligned}
$$

Koefisien b dinamakan koefisien arah regresi dan menyatakan perubahan rata-rata variabel $Y$ untuk setiap perubahan variabel $X$ sebesar satu satuan sehingga dari persamaan tersebut dapat diterjemahkan:

a. Konstanta sebesar 10,534 menyatakan bahwa jika tidak ada nilai pengetahuan mahasiswa tentang investasi maka nilai minat mahasiswa berinvestasi investasi di galeri investasi syariah IAIN Batusangkar sebesar 10,534

b. Koefisien regresi $\mathrm{x}$ sebesar 0,590 menyatakan bahwa setiap penambahan 1 nilai pengetahuan mahasiswa tentang investasi, maka 
nilai minat mahasiswa berinvestasi di galeri investasi syariah IAIN Batusangkar bertambah sebesar 0,590 .

\section{Pembahasan}

Penelitian ini bertujuan untuk menguji pengaruh pengetahuan mahasiswa tentang investasi terhadap minat mahasiswa berinvestasi pada galeri investasi syariah IAIN Batusangkar. Berdasarkan hasil analisis, maka pembahasan tentang hasil penelitian adalah pengetahuan mahasiswa tentang investasi $(\mathrm{X})$ berpengaruh positif secara parsial terhadap minat mahasiswa berinvesatsi pada galeri investasi syariah IAIN Batusangkar. Hal ini ditunjukkan oleh nilai koefisien regresi $\mathrm{X}$ sebesar 0,590 menyatakan bahwa setiap pengetahuan investasi sebesar 1 satuan akan meningkatkan minat berinvestasi sebesar 0,590 satuan. Nilai signifikan uji t sebesar $0,000<0,1$ maka hipotesis di terima. Ini berarti variabel independen mempunyai pengaruh signifikan terhadap variabel dependen.

Penelitian ini sesuai dengan penelitian Rizki Chaerul Pajar (2017). Prodi Akutansi Universitas Negeri Yogyakarta, dengan judul "Pengaruh Motivasi Investasi dan Pengetahuan Investasi terhadap Minat Investasi Di Pasar Modal Pada Mahasiswa FE UNY". pada penelitian ini (1) Motivasi berpengaruh positif terhadap minat investasi mahasiswa di pasar modal FE UNY. (2) pengetahuan investasi berpengaruh terhadap minat mahasiswa berinvestasi. Jadi pengetahuan ber- pengaruh terhadap minat berinvestasi. Semakin tinggi pengetahuan seseorang maka minat berinvestasi juga semakin tinggi.

\section{PENUTUP}

Berdasarkan hasil penelitian yang penulis lakukan dapat disimpulkan bahwa hasil pengujian $t$ signifikansi menunjukkan bahwa terdapat nilai sig sebesar 0,000 $(0,000<0,1)$. Dari hasil nilai tersebut menunjukan bahwa pengetahuan mahasiswa tentang investasi berpengaruh terhadap minat mahasiswa berinvestasi pada galeri investasi syariah IAIN.

Besarnya koefisien determinasi (R2) adalah sebesar 0,446. Hal ini menunjukan bahwa variabel independen mempengaruhi variabel dependen sebesar $44,6 \%$ sisanya sebesar $55,4 \%$ dipengaruhi oleh variabel lainnya.

\section{DAFTAR KEPUSTAKAAN}

Aini, N., Maslichah, \& Junaidi. (2019). EJRA Vol. 08 No. 05 Agustus 2019 Fakultas Ekonomi dan Bisnis Universitas Islam Malang. 08(05), 38-52.

Anisatus, S., \& Zainal, A. (2014). EFEKTIFITAS IKLAN POLITIK DI TELEVISI (Studi Deskriptif Kuantitatif Efektifitas Iklan Politik Aburizal Bakrie Versi Motivasi Anak Indonesia Pada Pemilih Pemula Di Surabaya). Jurnal Ilmu Komunikasi, 7(2), 1-10.

Baharuddin \& Wahyuni,E.N (2010). Teori Belajar dan Pembelajaran. Yogyakarta: Ar-Ruzz Media

38 | Pengaruh Pengetahuan Mahasiswa Tentang Investasi Terhadap Minat Mahasiswa Berinvestasi... 
Dalyono, M (2010). Psikologi Pendidikan. Jakarta: Rineke Cipta Daryanto

Haidir, M. S. (2019). Pengaruh Pemahaman Investasi, Dengan Modal Minimal Dan Motivasi Terhadap Minat Mahasiswa Dalam Melakukan Investasi Di Pasar Modal Syariah. 5(2), 198-211.

Hakim, L. (2016). Analisis Pengaruh Brand Image Terhadap Keputusan Konsumen Pada Bpr Sejahtera Batam. Jurnal Dimensi, 5(1), 1-15. https://doi.org/10.33373/dms.v5 i1.19

Hidayat, L., Muktiadji, N., \& Supriadi, Y. (2019). Pengaruh Pengetahuan Investasi Terhadap Minat Mahasiswa Berinvestasi Di Galeri Investasi Perguruan Tinggi. JAS-PT (Jurnal Analisis Sistem Pendidikan Tinggi Indonesia), 3(2), 63. https://doi.org/10.36339/jaspt.v $\underline{3 \mathrm{i} 2.215}$

Hidayati, A. N. (2017). No Title Investasi: Analisis Dan Relevansinya Dengan Ekonomi Islam. 8, 227-242.

Huda, N., \& Nasution, M.E (2008). Investasi pada Pasar Modal Syariah. Jakarta. Kencana Prenada Media Group

Khotimah, Husnul., Sabar Warsini dan Yeni Nuraini. Pengaruh sosialisasi dan Pengetahun Terhadap Minat Investor pada Efek Sayriah Di Pasar Modal. Jakarta: politeknik negeri Jakarta

Malik, A. D. (2017). Analisa Faktor Faktor Yang Mempengaruhi Minat Masyarakat Berinvestasi Di Pasar Modal Syariah Melalui Bursa Galeri Investasi Uisi. Jurnal Ekonomi Dan Bisnis Islam Uournal of Islamic Economics and Business), $\quad 3(1), 61$. https://doi.org/10.20473/jebis.v 3i1.4693

Manan, Abdul (2012). Hukum Ekonomi Syariah dalam Perspektif Kewenangan Peradilan Agama: Jakarta: Kencana Prenada Media Group

Mega, I. P., \& Semara, J. (2015). Kemampuan Pelatihan Pasar Modal Memoderasi Pengaruh Pengetahuan Investasi Dan Penghasilan Pada Minat Berinvestasi Mahasiswa. Jurnal Ilmiah Akuntansi Dan Bisnis.

Muhamad. (2016). Manajemen Keuangan Syariah: Analisis Fiqh \& Keuangan. Yogyakarta: UPP STIM YKPN

Mulyana, M., Hidayat, L., \& Puspitasari, R. (2019). Mengukur Pengetahuan Investasi Para Mahasiswa Untuk Pengembangan Galeri Investasi Perguruan Tinggi. JAS-PT Jurnal Analisis Sistem Pendidikan Tinggi, 3(1), 31. https://doi.org/10.36339/jaspt.v 3i1.213

Muri,Y. (2014). Metode Penelitian Kuantitatif, Kualitatif dan Penelitian Gabungan.

Jakarta: Prenadamedia Grup.

Nisa, A., \& Zulaika, L. (2017). Pengaruh Pemahaman Investasi, Modal Minimal Investasi Dan Motivasi Terhadap Minat Mahasiswa Berinvestasi Di Pasar Modal. Jurnal Penelitian Teori \& Terapan Akuntansi, 2(2), 22-35.

Pajar, Chaerul, Rizki. 2017. "Pengaruh Motivasi Investasi dan Pengetahuan Investasi Terhadap 
Minat Investasi di Pasar Modal Pada Mahasiswa FE UNY". Skripsi. Universitas Negeri Yogyakarta

Pertiwi, P. J., Tommy, P., \& Tumiwa, J., R. (2016). Pengaruh Kebijakan Hutang, Keputusan Investasi Dan Profitabilitas Terhadap Nilai Perusahaan Food And Beverages Yang Terdaftar Di Bursa Efek Indonesia. Jurnal EMBA 1369 Vol.4 No.1 Maret 2016, Hal. 1369-1380

Priyatno, Duwi. (2012). Cara Kilat Belajar Analisis Data dengan SPSS 20. Yogyakarta: Penerbit Andi

Priyatno, Duwi. (2014). SPSS 22 Pengolahan Data Terpraktis. Yogyakarta: Penerbit Andi

Sadulloh, Uyoh. 2007, Pengantar Filsafat Pendidikan. Bandung: Alfabeta

Sholeh, Khodirin. 2010. Integrasi agama dan filsafat. Malang: UIN-Maliki Press

Siregar, Syofian. (2013). Metode Penelitian Kuantitatif, Dilengkapi Perbandingan Perhitungan Manual \& SPSS. Jakarta: Kencana

Siregar, Syofian. (2017). Statistik Parametrik untuk Penelitian Kuantitatif, Dilengkapai dengan Perhitungan Manual dan Aplikasi SPSS Versi 17. Jakarta; Bumi Aksara

Sugiono. (2001). Metode Penelitian Pendidikan, pendekatan
Kuantitatif, Kualitatif dan R\&D. Bandung: Alfabeta

Sujianto, A. E. (2009). Aplikasi Statistik dengan SPSS 16.0 Jakarta: Prestasi Pustaka Publisher

Susanti, Hasan, Ahmad, et al. 2018. Faktor-Faktor Yang Mempengaruhi Minat Mahasiswa Berinvestasi Di Galeri Investasi Unoversitas Negeri Makasar. Makasar: Prosiding Seminar Nasional Pendidikan Ekonomi da Bisnis Islam. ISBN: 978-60260061-2-7.

Sutedi, Adrian. (2011). Pasar Modal Syariah: Sarana Investasi Keuangan Berdasarkan

Prinsip Syariah. Jakarta : Sinar Grafika

Surajiyo. 2010, Filsafat Ilmu Dan Perkembangannya Di Indonesia, Jakarta:Graha Ilmu

Santoso, Sigih (2010). Statistik Parametrik, Konsep dan Aplikasi dengan SPSS. Jakarta: PT Gramedia

Tandio, Timothius dan A.A.G.P. Widanaputra. 2016. Pengaruh Pelatihan Pasar Modal, Return, Presepsi Risiko, Gender, Dan Kemajuan Teknologi Pada Minat Investasi Mahasiswa.Ejurnal Akuntansi Universitas Udayana Vol. XVI, N0. 3, September.

Yuliana,Indah. (2010). Inestasi produk keuangan syariah. UIN- MALIKI PRESS (Anggota

IKAPI) 